\title{
The Treaty of Utrecht and Addison's Cato: Britain's War of the Spanish Succession, Peace and the Imperial Road Map
}

\author{
Samia Al-Shayban
}

I have this business of ye peace soe much at heart....

(QUEEN ANNE, 1711) $)^{1}$

Queen Anne's letter to her First Lord of the Treasury, Earl of Oxford, the leader of Tory party expresses her keen desire to procure the Peace of Utrecht for her war-weary nation. The Treaty of Utrecht was signed to end the War of Spanish Succession on 11 April 1713 amidst deep divisions in Queen Anne's government. The Queen, Oxford and their supporters in the government were seeking peace as a means of securing England's interests that the long war had failed to achieve. ${ }^{2}$ On the opposite side stood the war general, the Duke of Marlborough, and his Whig Cabinet allies who were adamant about continuing the fighting. ${ }^{3}$ Addison premiered Cato at Drury Lane on 14 April 1713 just a few days after the signing of the Peace of Utrecht amidst this foray of war and peace. It is no coincidence that the core of Cato is the conflict between those who seeks peace represented by Julius Caesar and the advocates of war under the leadership of Cato Uticensis.

From its first performance, the play proved to be an immediate success. On 30 April 1713 Alexander Pope, who attended the premiere, described the audience's enthusiastic reaction to Cato's struggle. In a letter to John Caryll, he wrote:

The numerous and violent claps of the Whig party on the one side of the theatre, were echoed back by the Tories on the other. ${ }^{4}$

1 Queen Anne to 1st Earl of Oxford, Robert Harley, 24 September 1711, Historical Manuscripts Commission [UK-Bath 1711] Ms 1:212. The letter is also quoted in Edward Gregg, Queen Anne (London: Yale University Press), 341.

2 Gregg, Queen Anne, 330-362.

3 Gregg, Queen Anne, 343-350.

4 The Correspondence of Alexander Pope, ed. George Sherbum (Oxford: Clarendon Press, 1956), I, 175 .

(C) KONINKLIJKE BRILL NV, LEIDEN, 2015 | DOI 10.1163/9789004304789_009 
According to Pope's letter, both the Whigs and the Tories tried to stress that they were the champions of virtue and liberty, the sentiments expressed in the play. Before the end of its first season, Cato had been staged more than twenty times. To meet the public demand it was performed the following season. ${ }^{5}$ Since its first performance, the play has attracted various critical readings. The critical ground shared by contemporary and modern critics concerns the face of Caesar's tyranny and empire. Alexander Pope's prologue to the play articulates eighteenth-century views. Popes declares

Here tears shall flaw from a more gen'rous cause, Such tears as patriots shed for dying laws:

He bids your breasts with ancients ardour rise, And calls forth Roman Drops from British eyes. Virtue confessed in human shape he draws, What Plato thought, and godlike Cato was [...] Who hears him groan, and does not wish to bleed? Ev'n when proud Caesar, midst triumphal cars. ${ }^{6}$ $(13-18,26-27)$

Modern criticism retains a similar approach to the play without attempting to untangle the controversy around its meaning. Laura Rosenthal reads Cato as a promotion of the struggle for 'a democratic Roman Republic' in the face of a 'corrupt and overreaching Roman Empire. ${ }^{7}$ Lisa Freeman believes that Cato's virtues are an allegorical presentation of patriotism in England. ${ }^{7}$ Frederic Litto, who reveals the deep ideological and cultural bond between Cato and the colonists in America, states:

Cato's last stand for liberty against the usurpation of Caesar found special sympathy in the hearts and minds of colonists. ${ }^{8}$

5 Lincoln Faller, The Popularity of Addison's Cato and Lillo's The London Merchant (New York: Garland, 1988).

6 Alexander Pope, 'Prologue to Cato by Joseph Addison,' The Broadview Anthology of Restoration and Early Eighteenth Century Drama, ed. J. Douglas Canfield (Toronto: Broadview Press, 2005), 187 .

7 Lisa Freeman, 'What is Love Got to do with Addison's Cato,' Studies in English Literature 1500190039 (1999): 463-482.

8 Frederic M. Litto, 'Addison's Cato in the Colonies,' William and Mary Quarterly 23:3 (1966): 431-449. 
A similar reading is expressed by Julie Ellison, who argues that Cato's relationship with the Numidian prince, Juba, is a testimony of republicanism's ability to transcend race and geography. ${ }^{9}$ In his well-known study of Augustan drama, John Loftis refrains from taking sides and insists that the political meaning of Addison's Cato 'was and is still an enigma.'10

\section{Propaganda, War of the Spanish Succession and Peace of Utrecht}

This paper attempts to expand Loftis' view and offers an explanation of Cato's enigmatic political message. To that end the play is read against the Treaty of Utrecht's historical context as imperial peace propaganda that supports peace and denounces the pursuit of war. Addison reaches this end by championing Julius Caesar and undermining Cato Uticensis through moral and military aspects. The championing of Caesar's stand is achieved through his physical absence from the dramatic scene, his character, and his pursuit of peace and a Roman empire. Cato, on the other hand, is undermined through his physical presence, character, the pursuit of war and a disintegrating Roman republic. Throughout this contrast, peace pointedly occupies most of the dramatic space while war remains in the background. This is achieved through allowing the characters to occupy themselves with discussing the reasons behind the choice between embracing or rejecting Caesar's peace. Within this context, Addison carefully and explicitly embedded historical events related to the War of the Spanish Succession and the Treaty of Utrecht. One can trace a close connection between Queen Anne's and Oxford's tactics to procure peace and those of Caesar. The dramatization of Cato's position in the war evokes a comparison with the French and the advocates of war. Through the contrast between Caesar and Cato, Addison invites the audience to recognize the different stand of each persona, not only dramatically but, most importantly, historically. Historical Caesar as a glorious military figure was part of British history, as the first Roman to invade England. His vision of a Roman empire became a reality. ${ }^{11}$ By contrast, Cato lost his republican cause and gave way to Caesar's

9 Julie K. Ellison, 'Cato's Tears,' ELH 63:3 (1996): 571-6o1.

10 John Loftis, Politics of Drama in Augustan England (Oxford: Clarendon Press, 1963), 57.

11 Bill Yenne, Julius Caesar:Lessons in Leadership from the Great Conqueror (London: Palgrave Macmillan, 2012), 193; Philip Freeman, Julius Caesar (London: Simon and Schuster, 2008), 243-342. 
victory and empire. ${ }^{12}$ Thus, Addison's Cato argues that Caesar's choice of peace over war proves to be an assured way to build an empire. By association, the British audience is encouraged to view the Treaty of Utrecht under a similar light and perceive it as a sign of power and a road map to building a British empire similar to that of the Romans.

Propaganda for the Peace of Utrecht and, by association, the Tory Ministry might seem odd under the light of Addison's well-known Whig sympathises. However, it should be noted that it was not unusual for men of letters like him to change sides. During Anne's era political propaganda rendered men of letters invaluable. Their writings became part of the power struggle between the rival parties, the Whigs and the Tories. The sharp division between the political parties over war and the Peace of Utrecht made it necessary to enlist writers who could voice their policies most eloquently. In such heated contexts, it was normal practice for writers to change sides. Daniel Defoe (1660-1731) and Jonathan Swift (1667-1745) are good examples of such behaviour. Swift and Defoe were two of the most influential writers of the era who played important roles in the propaganda for the War of the Spanish Succession and the Peace of Utrecht. Both authors became notorious for changing their political affiliations. Defoe supported William III's preparation for the War of the Spanish Succession. He continued his support for the war under Godolphin and his Whig Ministry only to change his mind and support the Peace of Utrecht under Oxford Ministry in 1710. He employed his periodical The Review (1704-1713) as his medium of showing his shifting loyalty. ${ }^{13}$ Dean Swift revealed similarly fickle affiliations. Before joining the Tories in 1710, Swift was employed by the Whig party as a propagandist. Oxford enlisted him as the editor of The Examiner to further the Tory's peace agenda. In 1711, Swift published The Conduct of the Allies and of the Late Ministry in Beginning and Carrying on the Present War. It is a work of peace propaganda that attacks the Austrians, the Dutch, the Whig Junto and, above all, Marlborough, the war general. It proved to be extremely influential as it increased the public and parliamentary support for the Treaty of Utrecht. Soon after the war general Marlborough was dismissed from office. ${ }^{14}$

Like Defoe and Swift, Addison played an active part in this conflict of war and peace long before Cato. After the victory of Blenheim in 1704, the Whig Lord

\footnotetext{
12 Rob Goodman and Jimmy Soni, Rome's Last Citizen: the Life and Legacy of Cato, Mortal Enemy of Caesar (New York: St. Martin's Press, 2012), 243-269.

13 William Minto, Daniel Defoe: A Biography (London: Create Space, 2012).

14 Leo Damrosch, Jonathan Swift: His Life and His World (Yale: Yale University Press, 2013), 164-252.
} 
Treasurer Godolphin approached Addison to write a commemorative poem. Addison composed The Campaign, a heroic celebration of the British victory. This celebration of victory was followed by The Present State of War, and the Necessity of an Augmentation, consider'd in 1707. The pamphlet was designed to oppose peace with France and promote the prolongation of the war. His propaganda for the Whigs gained him political offices and social prominence. ${ }^{15}$ By the time Addison staged Cato in 1713, he was a popular man of letters, not only because of his political affiliation but also as a result of his writings in The Tatler and The Spectator. ${ }^{16}$ As a producer of political propaganda, Addison was well aware that his play would be conceived as a political weapon. Rob Goodman and Jimmy Soni shed light on the context of staging Cato.

Addison completed the draft under pressure from his well-connected friends, prominent liberal Whigs who needed fresh ammunition against their Tory opponents. They saw Addison's unfinished play as a potentially valuable propaganda piece. ${ }^{17}$

It is true that Addison had Whig sympathies; however, he did not want to offend the Tories who were in power. He consented to the staging of Cato only after coaxing Pope who was a Tory to pen the play's prologue and convincing the Tory government censor to sanction its release. This permission would not have been granted had the Tory Ministry believed the play to be an attack against their Peace of Utrecht, and thus it indicates that Addison must have reached an agreement with the Tories regarding the content of the play. Some critics argue that Addison did not 'want to risk offending the Tories, who could squash his promising career. ${ }^{18}$ In addition to such a reasonable assumption one can also conclude that Addison was deliberately supporting the Tories and their Peace of Utrecht. Through his friendship with Swift, who abandoned the Whigs and wrote The Conduct of the Allies, which supported Harley's peace proposal, Addison was closely connected to the peace advocates. When The Tatler ceased publication on 2 January 1711, John Gay explained that

\footnotetext{
15 Alexander Staff and Charles Knight, A Political Biography of Joseph Addison (London: Pickering and Chatto, 2014).

16 George Simpson Marr, The Periodical Essayists of the Eighteenth Century (London: James Clark, 1923), 21-63.

17 Goodman and Soni, Rome's Last Citizen, 296.

18 Ibid.
} 
people were $[\ldots]$ driven to accept the alternative view that the Tatler was laid down 'as a sort of submission to, or composition with, the Government for some past offences. 19

Soon The Tatler was replaced with The Spectator. In 1711, Addison argued in The Spectator against the partisan attitude that dominated the political scene:

For my own part, I could heartily wish that all honest Men would enter into an Association, for the Support of one another against the Endeavours of those whom they ought to look upon as their Common Enemies, whatsoever Side they may belong to.... In short, we should not any longer regard our Fellow Subjects as Whigs or Tories, but should make the Man of Merit our Friend, and the Villain our Enemy. ${ }^{20}$

By stating his opposition to partisan politics, Addison can be seen preparing the ground for supporting the Peace of Utrecht that the war-weary nation desired.

\section{The General and the Stoic: Caesar's Friendship and Cato's} Alienation

To promote peace through championing Caesar, the Roman general, and undermining Cato, the illustrious stoic, is a challenging task. To balance the picture between a professional man of war and a stoic politician, Addison kept Caesar physically off the stage while Cato dominates its centre. To allow Caesar with his military might to be physically present, confronting the defeated stoic, could vividly revive the battles of Pharsalus ( $48 \mathrm{BC}$ ) and Thapsus (46 BC) in which Caesar defeated Cato and his Republican allies. ${ }^{21}$ In Addison's particular dramatic context, this would be a risky option, threatening his ability to generate the needed sympathy for Caesar's peace proposal and, by association,

19 George A. Aitken, introduction to The Tatler, by Joseph Addison and Richard Steel (London: Duckworth, 1899), accessed April 28, 2014, http://www.gutenberg.org/ files/13645/13645-h/13645-h.htm\#introduction.

20 Henry Morley, ed., The Spectator, 1:125 (London: George Routledge, 1891), accessed April 19, 2014, http://www.gutenberg.org/files/12030/12030-h/12030-h/SV1/Spectatorı. html\#section125.

21 Adrian Goldsworthy, Caesar's Civil War (Oxford: Osprey, 2001), 31-63; William Batstone and Cynthia Damon, Caesar's Civil War (Oxford: Oxford University Press, 2006), 33-142. 
the Peace of Utrecht. As Caesar is meant to be Addison's man of peace, bringing his mighty military image onto the stage would undercut his intended role as a peacemaker. Such dramatic manipulation enables Addison to screen off Caesar's military superiority and simultaneously empowers Cato. Furthermore, it creates a provisional balance of power between the two contenders. Having done that, Addison is in a safe position to mask his partiality towards Caesar.

The image Cato projects throughout the entire play has been summarized by one of his ardent supporters, his son Marcus. Talking to his brother Portius, he tells him that their father,

Pent up in Utica, he vainly forms-

A poor epitome of Roman greatness

And, covered with Numidian guards, directs

A feeble army and an empty senate,

Remnants of mighty battles fought in vain.

By heav'ns, such virtues joined with such success

Distract my very soul: our father's fortune

Would almost tempt us to renounce his precepts ${ }^{22}$

$(1.40-47)$

The picture given by Cato's dutiful son, though miserable, is tragically accurate. There is nothing impressive about Cato's political situation. His Senate is empty, his army is weak and his guards are not Roman but Numidian. Cato's insistence on producing a poor imitation of Rome's greatest achievements, a senate and an army, stresses his uninspiring situation. It also reflects, though implicitly, the unpopularity of his call. The greatness of Rome, which Cato promises to maintain, is nowhere to be traced around him. Marcus clarifies that the world that abandons his father ' $[\ldots]$ courts the yoke and bows the neck to Caesar' (1.39). Marcus' words which meant to degrade Caesar, simply weaken his father's position. While his father has few followers and a weak army, Caesar, on the other hand, is receiving the world's homage. Under such circumstances, Marcus reaches the conclusion that his father's misfortune is such that Marcus is tempted to abandon Cato's side. He says, ' $\ldots$ our father's fortune/Would almost tempt us to renounce his precepts' (1.46-47).

22 The edition used here is: Joseph Addison, Cato, in The Broadview Anthology of Restoration and Early Eighteenth Century Drama ed. J. Douglas Canfield (Broadview Press, 2005), 186-216. 
This contrast between the two men sets the tone for the entire play. Significantly, the contrast, though implicit, is highly complex. When we examine the structure of the contrast between the two men's characters, Caesar emerges as the one with the strong, favourable stand. Significantly, Caesar's negative and positive traits have been portrayed by his enemies, a fact that gives him credibility. Cato and his two sons, Portius and Marcus, portray Caesar as a bloodthirsty man who spreads war and death. Cato gives Decius, Caesar's messenger, a damning picture of his general:

[...] Alas, thy dazzled eye

Behold this man in a false light,

Which conquests and success have thrown upon him;

Didst thou view him right, thou'dst see him black

With murder, treason, sacrilege, and crimes. (II.161-165)

To Cato, Caesar's light does not come from within but rather from his own actions. Once these actions are examined carefully, one can discover that victorious Caesar is nothing but a murderer.

Portius and Marcus' picture of Caesar is identical to that of their father. Portius describes Caesar's actions:

\section{[...] Already Caesar}

Has ravaged more than half the globe and sees

Mankind grown thin by his destructive sword. (I.6-8)

Marcus follows his father and brother in giving a similar description of Caesar. He tells his brother:

$[\ldots]$-I see

Th' insulting tyrant prancing o'er the field

Strowed with Rome's citizens and drenched in Slaughter,

His horse's hoofs wet with patrician blood. (I.18-22)

One cannot help but notice that Cato's and his sons' attacks are directed against Caesar's military performance and achievements. According to the Roman moral code, such accusations would hardly undermine a victorious general such as Caesar. ${ }^{23}$ It is a well-known fact that military and political

23 Dorance Stirchfield White, 'The Attitude of the Romans toward Peace and War,' The Classical Journal 31:8 (1936): 465-478. 
achievements were inextricably connected in ancient Rome. ${ }^{24}$ The fourhundred-year-old Roman Republic of which Cato was one of its powerful senators was founded through the efforts of men such as Caesar who fought ambitiously bloody wars. ${ }^{25}$ Since Rome depended upon wars to extend its territories, it is no surprise that most of these wars were generally annihilating, especially towards formidable and challenging opponents. ${ }^{26}$ Cato himself was no stranger to Rome's ruthless and relentless military campaigns. In $72 \mathrm{BC}$ Cato volunteered to fight in the war against Spartacus. During Rome's war with Macedon, Cato served on the frontline commanding a legion. ${ }^{27}$ In such a context, Caesar is no different from Cato except that he is a victorious general. He managed to achieve what Rome mostly cherished: he extended its territories and displayed its military might. ${ }^{28}$

Indeed, not all of Caesar's enemies perceive him negatively. The Roman Senators Lucius and Sempronius along with the Numidians' General Syphax, although close allies to Cato, believe Caesar to be a man of unique qualities. Lucius believes Caesar to be merciful not only towards his friends but, most significantly, towards his enemies. He tells Cato, 'Caesar has mercy, if we ask it of him' (4.3. 129). Sempronius and Syphax decide to abandon Cato's cause and join Caesar. Sempronius explains that Cato's

[...] baffled arms and ruined cause

Are bars to my ambition. Caesar's favor,

That show'rs down greatness on his friends, will raise me

To Rome's first honors. (I.168-171)

In spite of the fact that Sempronius is practically Caesar's enemy, he nevertheless credited him with generosity and loyalty to his friends. He seems certain that he can fulfil his dreams of greatness by allying himself with Caesar. Historically, Caesar was known for his clemency and generosity, not only towards his friends but most significantly towards his political opponents. ${ }^{29}$

24 William Vernon Harris, War and Imperialism in Republic Rome, 327-70 BC (New York: Oxford University Press, 1985), 9-53.

25 Adrian Goldsworthy, In the Name of Rome: The Men who Won the Roman Empire (Phoenix: Phoenix Press, 2004).

26 Barry Strauss, The Spartacus War (New York: Simon and Schuster, 2010); see also Adrian Goldsworthy, The Fall of Carthage: The Punic Wars 265-146 BC (London: Cassell, 2007).

27 Goodman and Soni, Rome's Last Citizen, 39-68.

28 Freeman, Julius Caesar, 328-342.

29 Ernle Bradford, Julius Caesar: the Pursuit of Power (New York: E-Reads, 2013), 11-12. 
Thus, Sempronius' hope for Caesar's rewards is not mere speculation but a prize that can be achieved. Sempronius describes Caesar's character not only in time of peace but in war as well. He gives Syphax a description of Caesar's performance as a general:
Alas! Thou know'st not Caesar's active soul, With what dreadful course he rushes on From war to war. In vain has nature formed Mountains and oceans to oppose his passage; He bound o'er all, victorious in his march. The Alps and Pyreneans sink before him; Through winds and waves and storms he works His way, Impatient for the battle. (I.182-189)

Addison's description of Caesar's performance during his military campaigns is detailed, rather lengthy and, most importantly, historically accurate. Modern analysts paint a picture identical to the one detailed by Sempronius. Wesley Clark writes that

As a warrior, Caesar was extraordinarily competent [...]. He also had extraordinary endurance and stamina, campaigning without let-up for years, travelling on horseback, boat, and foot from Britain, Switzerland, Croatia, Italy, and back [...]. He was a master at the use of quick combat Engineering, in the form of earthworks, bridges, and boats [...]. Caesar was a master of war and politics. ${ }^{30}$

Fidelity to Caesar's historical reputation and providing a lengthy and detailed description of his unique character as a military general through one of his enemies show that Addison is far from undermining him. In fact he is subtly and surely championing Caesar at the expense of Cato. Sempronius' glowing account makes up for Caesar's physical absence from the stage as it ensures the audience's full awareness of his extraordinary talent as a leader and his loyalty as a friend. Through Sempronius' portrayal, Caesar emerges as an embodiment of the Roman virtus. Virtus is a Roman moral concept that highlights manliness by means of outstanding military achievements. ${ }^{31}$ Under this moral

30 Wesley Clark, foreword to Julius Caesar: Lessons in Leadership from the Great Conqueror, by Bill Yenne (London: Palgrave Macmillan, 2012), vii-ix.

31 Myles McDonell, Roman Manliness: 'Virtus' and the Roman Republic (Cambridge: Cambridge University Press, 2009), 12-71, 107-141, 300-319. 
system it is the duty of a Roman to serve the public interest of Rome through politics and military victories. As a result, conquests and expansions became part of the collective duty of Roman society. ${ }^{32}$ The fact that Cato fails to recognize and appreciate Caesar's virtus calls into question his stoic moral values and consequently his ability to offer an objective moral judgement.

In contrast to Caesar's engaging image, Addison furnishes Cato with an unflattering persona. This is done by undermining the most important component of Cato's character, his stoic moral values, and by providing him with the partial praises of his supporters. ${ }^{33}$ Cato's stoic values are undercut by the Numidian general Syphax. Syphax, whose army is supposed to fight on Cato's side, denies Cato any special moral merits. He questions the morality of the famous Roman stoic ideal of self-control. He asks Juba, the Prince of Numidia:

What are these wondrous civilizing arts,

This Roman polish, and this smooth behavior,

Are they not only to disguise our passions,

In short, to change us into other creatures

Than what our nature and the gods designed us?

(I.275-6,279,282-3)

To the African Syphax, stoic self-control is nothing but moral hypocrisy as it disguises one's real feelings. Furthermore, it is a break from genuine and free human nature. In response to the hardships that mark Cato's diet and lifestyle, Syphax tells his Prince:

Believe me, Prince, there's not an African

that traverse our vast Numidian deserts

But better practices these boasted virtues.

(I.294-295,297)

Syphax insists that the simple and rough life of of the vaunted Cato is but the normal practice of ordinary Africans. After denying Cato any unique virtues, Syphax argues that his stoic teachings are neither popular nor inspiring. $\mathrm{He}$ informs Sempronius that the Numidians who are fighting with Cato are

32 Harris, War and Imperialism, 9-53.

33 Rex Stem, 'The First Eloquent Stoic: Cicero on Cato the Younger,' Classical Journal 101:1 (2005): 37-49; Goodman and Soni, Rome's Last Citizen, 36-39; see also Brad Inwood, The Cambridge Companion to the Stoics (Cambridge: Cambridge University Press, 2003), $233^{-256 .}$ 
$[\ldots]$ ripe for a revolt. They all

complain aloud of Cato's discipline

and wait but the command to change their masters.

(I.176-178)

The Numidian soldiers who are used to tough fighting conditions find it difficult to cope with Cato's style. As a result they are eager to change sides and join Caesar because Cato is not an inspiring leader who can procure loyalty from his followers. According to Syphax, Cato is not only uninspiring, but he also lacks the human touch. Prince Juba describes Cato's endurance, declaring: 'How does he rise against a load of woes / And thank the gods that throw the weight upon him!' (I.316-317) In response, Syphax expresses his opinion of Cato's behaviour: 'Tis pride, rank pride, and haughtiness of soul: / I think the Romans call it stoicism.' (I.318-319) Cato's failure to display human sentiments can best be perceived through his passive response to his son's death. Cato has been informed that his son Marcus

$[\ldots]$ stood the shock of a whole host of foes.

Till, obstinately brave and bent on death,

Oppressed with multitudes, he greatly fell. (IV.3.71-73)

To such news, Cato responds, 'I'm satisfied' (IV.3.74). When presented with the body, he not only remains unmoved but celebrates the sight of his dead son's fatal wounds:

Welcome, my son! Here lay him down,...

Full in my sight, that I may view at leisure

The bloody course and count those glorious wounds

(IV.3.87-89)

Cato's failure to reveal any signs of emotion or grief over his son's death is difficult to comprehend. Most significantly, it gives credibility to Syphax's judgement that Cato lacks human compassion. In the context of war over the fate of Rome, Cato's stoicism is hardly relevant. It shapes him as a private individual but not as a public figure. One notices that stoicism, which is Cato's most valued quality, is also the factor that alienates him from those around. As a result, his moral system remains tragically individualistic, which explains Cato's constant misfortunes and failures to affect the course of events around him. On the other hand, Caesar, who is not a stoic, has the moral power to persuade others to help him achieve his vision. Caesar does not appear as 
an isolated individual like Cato but rather as a mobile and attractive force. Comparing the two men makes Addison's message clear. Rome's salvation does not require a man like Cato who fails to inspire those around him into action. Rome needs a Caesar who is both accessible and at the same time inspiring. It should be noted that Addison had constructed a moral contrast between Caesar and Cato before staging the play. In The Spectator, Addison wrote:

In [the]... Passage of Salust, where Ceesar and Cato are placed in such beautiful, but opposite Lights; Caesar's Character is chiefly made up of Good-nature, as it shewed itself in all its Forms towards his Friends or his Enemies, his Servants or Dependants, the Guilty or the Distressed. As for Cato's Character, it is rather awful than amiable. Justice seems most agreeable to the Nature of God, and Mercy to that of Man. ${ }^{34}$

Addison renders Caesar as a most agreeable man. The same thing cannot be said about Cato whom Addison finds far from amiable. Publishing such an opinion in the widely read and popular Spectator shows that Addison's championing of Caesar is a genuine conviction. It is highly likely that those readers who follow him closely will be affected by his support of Caesar and condemnation of Cato. In the context of Cato and the controversy surrounding the Peace of Utrecht, the audience would find themselves more sympathetic with Caesar's call for peace.

To further cast shadow on Cato's character Addison allows him to be the subject of partial praise. Cato is praised by his son Portius and his protégée, the young Prince Juba of Numidia. Cato here stands in sharp contrast to Caesar, who has been generously praised by his opponents. Portius pays compassionate homage to his father.

How does the luster of our father's actions,

Through the dark clouds of ills that cover him,

Break out and burn with more triumphant brightness! (I. 28-31)

The homage that is paid by a devoted and loving son does not help Cato on the moral and political fronts. The compassionate words give contrasting images between his father's actual defeat and metaphorical triumph, which in turn highlights Cato's weak position and produces an unfavourable

34 Morley, The Spectator, 1:169, http://www.gutenberg.org/files/12030/12030-h/12030-h/SV1/ Spectatori.html\#section169, accessed 14 April 2014. 
contrast between him and Caesar. Juba, in his turn, praises Cato with undeniable enthusiasm. He wonders

Where shall we find the man that bears affliction, Great and majestic in his griefs, like Cato?

Heav'ns, with what strength, what steadiness of mind

He triumphs in the midst of all his sufferings! (I.312-315)

Juba is as impressed with Cato's stand in the face of his misfortunes as is his son Portius. The way Juba describes Cato stresses his sentimental attachment to Cato. To the young inexperienced Prince, Cato is a father figure. His father King Juba, who was Cato's friend and ally, died fighting on his side against Caesar. Furthermore, Cato is the father of his love, Marcia. Such sentimental attachment colours Juba's favourable attitude towards Cato by impugning his impartiality.

\section{Utrecht and the Empire: Caesar's Peace and Cato's War}

In a further step to champion Caesar and undermine Cato, Addison contrasts their attitudes towards war and peace. He allows the victorious Caesar to pursue peace while the defeated Cato seeks war. To understand the significance of Addison's manipulation of war and peace we need to consider the military context of the conflict between Caesar and Cato. The events are taking place immediately after Caesar's decisive victory at Pharsalus and Thapsus. With such decisive victories Caesar does not need to court the defeated and weak Cato to accept his peace proposal. However, Caesar displays unrelenting determination to procure peace in the face of Cato's adamant rejection. By 1710, England was in a position similar to that of Caesar. Like Caesar England's forces had achieved decisive victories in several battles. They won Blenheim in 1704 , Ramillies in 1705 , Oudenaarde in 1708 and Malplaquet in $1709 .{ }^{35} \mathrm{In}$ spite of England's advantageous military position, the Queen and her minister Oxford were determined to achieve peace and sign the Treaty of Utrecht. Before Caesar's peace proposal is revealed, Addison stresses that peace is the sacred demand of the gods. Cato's friend and ally, Lucius, urges the Senate to accept peace. He informs them: 
My thoughts, I must confess, are turned on peace.

Already have our quarrels filled the world

With widows and with orphans: Scythia mourns

Our guilty wars, and earth's remotest regions

Lie half unpopulated by the feuds of Rome.

'Tis time to sheathe the sword and spare mankind.

It is not Caesar but the gods, my fathers,

The gods declare against us and repel

Our vain attempts.

Now let us show submission to the gods.

(II.56-56-46,69)

Lucius declares that Caesar's victories and peace proposal are the designs of the gods. Addison is in effect claiming Caesar to be a sacred entity favoured by the gods. He is the instrument of the gods who executes their victorious wars and procures their wishes for peace. Thus, peace becomes a sacred mission that has to be embraced and accomplished. To Queen Anne peace was a sacred wish as well. Edward Gregg argues that 'the queen's anxiety to procure peace had a harmful effect on her health. ${ }^{36}$ In a manner similar to Lucius, the Queen and her government urged the parliament to accept peace. She was concerned to the point of warning Oxford, 'we cannot part with one vote out of house of Lords. ${ }^{37}$ One can notice that Lucius' arguments to Cato's Senate, criticizing the warring factions, echo Swift's position in The Conduct of the Allies in which he takes to task all parties involved in the war and calls for an end to the shedding of blood and wasting of treasure. Caesar's desire to stop the war and establish peace motivates him to take calculated steps to ensure the success of his proposal. This is apparent through his choice of Decius as his peace messenger to Cato. The man Caesar has chosen to be his messenger was Cato's friend. Cato confirms their past friendship to the Senate: 'Decius was once my friend, but other prospects / Have loosed those ties and bound him fast to Caesar' (I.108109) The fact that Caesar has chosen one of Cato's former friends to be his messenger indicates that he has a strong desire to influence Cato and secure peace. Decius reminds Cato of their friendship and reveals his current mission: '[...] I have orders to expostulate / And reason with you, as from friend to friend: [...]'

\footnotetext{
$36 \quad$ Ibid., 343 .

37 Queen Anne to 1st Earl of Oxford, Robert Harley, 9 November 1711, Historical Manuscripts Commission [UK-Bath 1711] Ms 1: 215-16. The letter is also quoted in Gregg, Queen Anne, 344 .
} 
(I.127-128) The arrival of the messenger and the confirmation of his mission to negotiate peace remind Addison's audience of the British negotiation of Peace of Utrecht with Louis XIV in Paris. The Tory Ministry posed as the friend of the French. They conducted exclusive secret negotiations with the French based on a balanced view of the interests of both countries. ${ }^{38}$ The negotiations Decius starts with Cato are exclusive as well. Cato's other generals and partners are excluded. As a show of good will, Decius starts by declaring:

My business is with Cato: Caesar sees

The straits to which you're driven and, as he knows

Cato's high worth, is anxious for his life. (II.1. 115-117)

Decius reminds Cato of his unpromising position as a result of his military defeats. He also stresses Caesar's appreciation of Cato's character and concern for his physical safety. When the Tory government was negotiating peace with Louis XIV in 1710, France like Cato was on the brink of ruin. The French had suffered costly defeats in several battles. By 1709 the allied armies under the leadership of Marlborough were 'in the best position ever for an invasion of France. ${ }^{39}$ Like Caesar, who was desperate of save Cato's life, Oxford wanted to prevent the utter destruction of his enemies. Oxford's attitude was motivated by his desire to save the Treaty of Utrecht. Such a tactic would secure 'the separate and exclusive advantages on which the secret Anglo-French negotiations were based. ${ }^{40}$ To persuade Cato to choose peace, Decius reminds Cato that Caesar is the victor and that

Rome and her Senators submit to Caesar;

Her Gen'rals and her consuls are no more,

Who checked his conquests and denied his triumphs.

(II.1. 122-124)

Politically and militarily, Caesar is in an unchallenged position. The Roman Senate supports him. His military and political opponents have lost their power. When the play was staged, Britain was in an identical situation. To eliminate any obstacles and secure the Peace of Utrecht, Queen Anne had taken major steps. She created twelve peers in the House of Lord and dismissed her war general, Marlborough, who rejected a royal request to support the peace

$\begin{array}{ll}38 & \text { Gregg, Queen Anne, } 335 . \\ 39 & \text { Ibid., } 343 . \\ 40 & \text { Ibid., } 356 .\end{array}$


proposal. ${ }^{41}$ Anne and her government were thus in unchallenged position just as Caesar was.

In response to Caesar's keen calls for peace, Cato is courting war. Before the arrival of Caesar's messenger, Cato expresses his determination to go to war. $\mathrm{He}$ informs the Senate of his opinion regarding their current situation:

Fathers, I cannot see that our affairs

Are grown thus desp'rate. We have bulwarks round us;

within our walls are troops inured to toil

In Africk's heats and seasoned to the sun;

Numidia's spacious kingdom lies behind us,

Ready to rise at its young prince call. (I.85-90)

It is of note that Cato is defending Rome with the aid not of a Roman army but of Numidian forces. This means that these forces may not be committed to Cato's cause. Indeed they have proven their lack of enthusiasm and loyalty through abandoning him and killing his son Marcus. Being a Roman is of high importance as characters struggle to prove their moral and military worth. Cato displays moral hypocrisy through using Africans in his war for Rome while stressing their inferiority to his position as a Roman senator. Dying, he tells his daughter, Marcia

[...] Juba loves thee, Marcia

A senator of Rome, while Rome survived,

Would not have matched his daughter with a king,

But Caesar's arms have thrown all distinctions: [...] (v.1.19o-194)

He makes it clear that his loyal ally Prince Juba, whose father sacrificed his life and army for Cato, is not fit to marry his daughter. However, necessity makes the marriage possible. Such an attitude weakens Cato's moral position and undercuts his loud voice against oppression and tyranny.

The same lack of good will is present when Cato meets Decius, Caesar's messenger. He rejects Caesar's concern for his life and responds to Decius's entreaties: "Tell your dictator this, and tell him Cato / Disdains a life which he has pow'r to offer.' (II. 120-121) Furthermore, he refuses the offer of Caesar's friendship as he insists that 'His cares for me are insolent and vain. / Presumptuous man! The gods take care of Cato.' (II. 173-174) As Cato is inclined towards war,

$41 \quad$ Ibid., $345^{-350 .}$ 
he asks for a high price in return for peace. Decius asks Cato, ' $[\ldots]$ name your terms'. To such a generous offer, Cato responds:

Bid him disband his legions,

Restore the commonwealth to liberty,

Submit his actions to the public censure,

And stand the judgment of the Roman senate. (II.141-144)

Cato is fully aware that Caesar will not submit to his terms. Such demands can be read as an indirect way of rejecting peace and choosing war. To prevent Cato from enjoying any heroic stand against the victorious Caesar, Addison allows Cato's friends, Decius and Lucius, to criticize his refusal to forge peace. Decius expresses his deep sorrow:

When I relate hereafter

The tale of this unhappy embassy,

All Rome will be in tears. (II.181-183)

These lines, though they are about Cato, are designed to promote Caesar's cause and his peace proposal. Rome will be in tears as Cato rejects Caesar's peace proposal and seeks war. This means that though Rome cares for Cato, it values peace above all else. Lucius, one of Cato's most loyal friends, once again confirms his preference for peace. After Cato's rejection of Caesar's embassy, Lucius stresses that peace is one of the options a Roman patriot can choose in the service of Rome. Lucius answers Sempronius, who desires to die while defending Rome, by stating,

\section{[...] Others perhaps}

May serve their country with as warm a zeal,

Though 'tis not kindled into so much rage. (II.1.202-4)

These lines can be read as a defence of those who favour peace and reject war against any treasonable accusations. For his role in bringing about the Peace of Utrecht, Oxford was accused of treason. He was suspected of championing the Jacobites and their desire to restore the Pretender, the queen's Catholic halfbrother. Marlborough was one of Oxford's enemies who warned the Queen against Oxford and his peace proposal. Indeed the Peace of Utrecht's terms proved those involved to be patriots who did their best to serve the British interests. Louis XIV expelled the Pretender from France, recognized Anne as 
the legitimate queen of England and accepted the Protestant succession. The British were allowed to retain Gibraltar and Port Mahon, thus becoming the dominant naval power in the Mediterranean. They were also given the monopoly of the Spanish slave trade for thirty years. As a result of Utrecht, Britain not only became a major power but most importantly started on the road to becoming an empire.

Cato and Caesar's conflicting roles regarding peace and war are firmly connected to their dramatic personae and historical legacies. This firm connection is of significance to Addison's period, which was dominated by the War of the Spanish Succession and the Treaty of Utrecht that ended the war. Dramatically, Caesar emerges as an ideal man not only of war but most significantly of peace. His determination to procure peace in spite of his military superiority shows him to be a man of strategic vision. War, on the other hand, is dramatized as the tragic choice of his opponents. Cato, who promotes war and opposes Caesar's calls for peace, is defeated on both military and moral levels. Cato lost his life and republic. Caesar, on the other hand, lived to play a crucial role in turning the Roman Republic into an empire that ruled the world for more than eight hundred years. Caesar was the first Roman general to invade Britain, which became a Roman territory for four hundred years. As a result, the English can identify themselves with victorious Caesar and the Roman Empire. They have a Roman heritage that can motivate them to build an empire like that of the Romans. Queen Anne, who desired very much to end the War of the Spanish Succession, can be viewed as a Caesar in her choice to sign the Peace of Utrecht Treaty in the face of fierce opposition from the Whig party. It is the terms of the Peace of Utrecht and not war that enabled Britain to start on the road towards an empire similar to that of the Romans. In the dramatic and historical contexts, Caesar and not Cato proved to be the man of the moment. 